\title{
検査デバイスや症候学的スキルを駆使した地域住民へのヘルスアセスメント
}

\author{
赤川信一郎, ${ }^{*, a}$ 森川則文, ${ }^{b}$ 池田佳代, ${ }^{b}$ 岡崎照夫, ${ }^{a}$ 高橋俊輔 ${ }^{a}$
}

\section{Health Assessment of Local Residents Who Made Full Use of Symptomatology Skills and Test Device}

\author{
Shinichiro Akagawa, ${ }^{*, a}$ Norifumi Morikawa, ${ }^{b}$ Kayo Ikeda, ${ }^{b}$ Teruo Okazaki, ${ }^{a}$ and Shunsuke Takahashi ${ }^{a}$ \\ ${ }^{a}$ Drug39 CO., LTD; 3-1-13 Kurogawanishi, Moji-ku, Kitakyushu 801-0825, Japan: and \\ ${ }^{b}$ Hiroshima University School of Pharmacy, Clinical Drug Treatment Laboratory; \\ 1-2-3 Kasumi, Minami-ku, Hiroshima 734-8551, Japan.
}

(Received July 22, 2014)

\begin{abstract}
A strategy named "Japan is back" adopted in June 2013 specifies that pharmacies shall be regarded as communitybased places where health-related information is provided, and the public shall be encouraged to use the services of pharmacies and pharmacists who can advise on health and appropriate use of over-the-counter (OTC) drugs, and promote self medication. In Japan there are approximately 55000 pharmacies and 260000 pharmacists, and community residents are recommended to use these resources. As advisors on healthcare in the community, pharmacists are required to make judgments regarding drug use in individuals performing self medication and using OTC drugs in consideration of their symptoms and level of understanding of their health conditions, and recommend that they consult a medical center if necessary. To meet these requirements pharmacists need to have the skills to monitor each individual's lifestyle, behavior, and environment as well as trends in society, and assess their health status. However, education that allows pharmacists to practice such skills remains insufficiently developed. We consider that to be able to detect diseases early among community residents and appropriately support them using pharmacotherapy, it is very important to train pharmacists to do the following at pharmacies: 1) determine individuals who should be treated early using symptomatologic skills; 2) promote public awareness of disease; and 3) perform biochemical examination (blood is collected by fingerprick promptly to obtain biochemical data) in cooperation with the Department of Clinical Pharmacotherapy, Faculty of Pharmaceutical Sciences, Hiroshima University.
\end{abstract}

Key words — health assessment; self-medication; test device

\section{1. 序論}

2014 年 4 月，新たな診療報酬改定を迎えた日本 の医療制度は，薬局そして薬剤師の職能に関しても 大きな転換期となることが予測される.

なぜなら，この報酬改定と「薬局の求められる機 能とあるべき姿」1)が明示されることによって，こ れまで処方せんによる調剤だけで成り立っていた薬 局経営が変化していくことが確実だからである.

具体的には，在宅医療への係わりを評価するため に基準調剤加算という施設基準には在宅での薬学管

$a$ 株式会社サンキュードラッグ（†801-0825 北九州市 門司区黒川西 3-1-13), ${ }^{b}$ 広島大学薬学部臨床薬物治療 学研究室（干734-8551 広島市南区霞 1-2-3)

*e-mail: s_akagawa@drug39.co.jp

本総説は, 日本薬学会第 134 年会シンポジウムS20 で 発表した内容を中心に記述したものである。
理指導の実績が必要になったことや，在宅療養して いる患者などが休日・夜間においても適切な医療を 受けることができるよう，24 時間調剂等に対応す ることが必要条件として設定したことが挙げられる.

そのほか, 後発医薬品の調剤率に関してハードル を高め，お薬手帳というパーソナルデー夕を持ち歩 くためのノートを活用するよう指導し，実際に活用 されているか否かによっても報酬が変わるよう改定 された.

このような背景には，日本の国民医療費の増加が あることは言うまでもないが，政治誘導的に医薬分 業が推進されてきた時期より，処方せんが薬局の入 場券となってしまっている調剤専門薬局の現状を, 今後われわれのような薬局薬剤師がどのように行動 するか，そして薬剤師になろうとする人がどのよう な教育を受けるべきか再考するよいきっかけである. 


\section{2. 地域密着型の薬局 ·薬剂師}

そのような中，わが国は健康日本 21 (第 2 次） において『地域住民が身近で気軽に専門的な支援・ 相談が受けられる民間団体の活動拠点数の増加』を 掲げ，その活動拠点の例として「地域住民の健康支 援・相談対応等を行い，その旨を積極的に地域住民 に周知している薬局」と明記した. ${ }^{2)}$

また，日本再興戦略における薬局・薬剤師の活用 として,「薬局を地域に密着した健康情報の拠点と して，一般用医薬品等の適正な使用に関する助言や 健康に関する相談，情報提供を行う等，セルフメ ディケーションの推進のために薬局・薬剤師の活用 を促進する」とも明記した. ${ }^{3)}$

しかしながら，この地域に密着した総合的な健康 情報拠点となるためには，2つの課題が存在すると 考える.

1つ目は，現状では「医師を受診するときにしか 訪れない，ときには 2 カ月に 1 度しか訪れない薬 局・薬剤師」が地域密着と言えるかどうか.

2つ目は，1つめの課題を含め，政策には「こう あるべき，何をなすべきか =What to do?」という ゴールは示されているが，「どうやって効果的に実 現するか =How to do?」という実践論としてのイ ンパクトが不足していることだ.

筆者は，地域密着すなわち身近さとは，次のよう なことだと考える.

【(1)距離】単に家から近いという物理的なことで あり，また「この薬剤師は話し易いな」というょう な精神的なことでもあり，またその薬局が社会にど のように貢献しているのかと俯瞰的に感じる倫理的 距離ではないか, ということ.

【(2)深い情報把握】もう 1 つの身近さとは，“自分 のことをどれくらいのレベルで知っているか”とい うことであるが，この要素は非常に重要だと考え る。なぜなら，例えば『低用量アスピリンによる脳 梗塞再発防止治療を受けている $\mathrm{A}$ さん』という情 報と，『低用量アスピリンを服用している $\mathrm{A}$ さんは その後遺症で日常生活にも不便が生じており, 介護 サービスを利用している．しかしへルパーからは運 動できないわりに間食を多く摂つており血糖值が上 昇しているということも情報共有している』という レベルの情報とでは，その価值の差は歴然であるか らだ.
つまり，1つめの距離が近いというメリットを最 大限に活用し，患者のみならず患者の生活者として の側面を知る人との接点を持ち，専門職として情報 を整理し，判断すること．これこそが国・国民が求 めている地域密着ではないだろうか.

\section{3. 地域密着企業の取り組み}

筆者が所属する株式会社サンキュードラッグは福 岡県北九州市と山口県下関市に密着した，かかりつ けネットワークを構築するために店舗網を整備し, 薬歴を患者同意の下，共有し，ドラッグストアと調 剤薬局を併設したスタイルを確立することで，患者 の生活者としての側面までをもフォローする体制を 整えている。 その体制を活かし，薬局内で行うイべ ントと, 自治体との共催により 2000 人規模の健康 イベントを実施している.

薬局内でのイベント，すなわちへルスケアステー ションとしての役割を果たすため月 1 回 8 カ所でイ ベントを実施し, 地域住民への啓発活動を行ってい る。ここまでは国が示した方針にそった状態で 「What to do?」に対する行動はできているという 状態である.

では，地域住民の健康寿命を延ばすためには，こ の機会をどのように活用すべきか?

その切りロとして重要なことは, 本シンポジウム テーマでもある「即断できる臨床能力とは何か?」 であり，それは前述の通り「患者や地域住民ひとり ひとりに対して，われわれがどのレベルで知ってい るか」という要素をどうやって活用するかが大事で ある、

なぜなら患者は，地域の中においてはひとりの生 活者であり，医療情報のみならず生活の嗜好を知つ たうえ，身体から得られる客観的情報を得ることで より的確な判断と情報提供が可能となると考えるか らだ.

ヘルスアセスメントは薬剤師に求められる重要な 臨床能力である.

イベントによって生まれた地域住民との接点も, 単に疾患についてのお話をする，訪れた方の認識・ 感情に同調するだけの相談では目標は達成されず, “ヘルスアセスメント”の実践あってこそ，患者の 行動変容を促せるのだと考える.

われわれは，2010 年より広島大学大学院医歯薬 保健学研究院臨床薬物治療学研究室との共同研究と 
して，医師との連携による薬局店頭でのプロトロン ビン時間一国際標準化比率（PT-INR）測定を始め た．その後，患者や地域住民の自己穿刺による血液 採取と検査值測定を通して様々な活動を行ってきた.

その 1 つが, 2012 年度から 2 年間にわたり, 計 162 回実施した店舗内でのイベントにおける生化学 検査である。測定項目は主としてメタボリックシン ドロームの早期発見を目的としてへモグロビン A $1 \mathrm{c}$ $(\mathrm{HbA1c})$, 総コレステロール，中性脂肪など関連 項目を，ドラッグストア店頭にて“健康な人”，“健 康だと思っている人”，また既になんらかの治療を 受けている人への測定を実施し, 慢性疾患のスク リーニングや治療継続の重要性を再認識するための 接点として活用した.

なお，イベントを実施している店舗では管理栄養 士も常駐しているため，連携によって運動や食事内 容の変更などの予防行動を促すことも少なくない.

この自己穿刺による血液採取は，平成 26 年 2 月 に厚生労働省と経済産業省によって，グレーゾーン 解消制度というシステムにおいて『自己採血と，そ れによって得られるデー夕を基に一般用医薬品を紹 介する，受診勧奨を行うことが医師法に定められる 「医業」に該当しない』と明記された. ${ }^{4}$

これによって，全国的にこのような活動が広がつ ていくのではないかと予想する。しかしながら，た だ数值を得ることに終始しても，ヘルスアセスメン 卜は実現されることはなく，そのデー夕を医療情報 や生活情報と組み合わせ，総合的にその方の状態を アセスメントすることによって適切なフィードバッ クを行うことが求められる.

それはときにはより強固な服薬管理であり，受診 勧奨であり，また多職種との協働によって，現在健 康な人に対して予防の視点で介入し, 行動変容を起 こすことである.

\section{4. ヘルスアセスメントを実践する教育の必要性}

ヘルスアセスメントは生活習慣病予防に限ったこ とだけではない。これまでわれわれが取り組んでき た「データを得る」ということに加え「データで読 み取れないもの」についても考える必要がある.

データで読み取れないもの，それは「訴え」であ る。この「訴え」は，あくまで主観的な情報だが， それをわれわれ薬剤師がどのように質問するか? そしてその返答に対して推測を巡らし，「この人に
対していま何をすべきか」と，自身が起こすべき行 動を即断しなければならないのである。われわれ は，薬剤師が店頭で求められる能力としては以下の 3つが挙げられるのではないかと考えている.

その 1 つ目は,「顧客の状況を理解する能力」.

顧客から症状など必要な情報が得ることができる ことと, 症状から病状を的確に把握できる能力のこ とである。

2 つ目は，「状況に応じ適切な医薬品を選定する （又はアドバイスや受診勧奨を行う）能力」.

例えば症状のメカニズムについて説明したり，症 状より一般用医薬品の選択や受診勧奨ができたりす るための能力である。

3 つ目は，「薬の知識を分かり易く伝える能力」.

これには一般用医薬品の選択理由を説明し, 納得 させることや一般用医薬品の服薬指導が含まれる が，同時に，薬剤師が対応できず受診しなければな らない理由を説明し，納得してもらえる能力という のも必要である.

われわれはこれらを実現するには，薬局薬剤師に 対しても症候学的スキルが必要だとして過去 6 年に わたり, 広島大学の森川則文教授による臨床薬学セ ミナーを企画・受講してきた.このセミナーの目的 は，まず主訴から疾患をイメージするトレーニン グ，そして実際に医師が処方決定するまでの思考プ ロセスを学ぶためである。

そして，この知識を薬局においては一般用医薬品 販売や相談応需に活かすためにどうするかという実 践論として考えた結果，新たな教育が生まれること となった。

それは，薬剤師が学ぶベきセルフメディケーショ ンの知識や医師の思考プロセスを，現場薬剤師が集 積してきた商品知識と経験に融合させることである.

われわれは，プライマリケアマニュアルの考え方 を軸に，本シンポジウムオーガナイザーである大井 教授の著書，そして内科診断学をべースとして社内 資料を作成した。この中では，顧客の訴えに対して 考えるべきことを系統だて，受診勧奨すべき状態に ついて共通認識を持つことができるようにしている.

また，商品知識とその蕰蓄なども交えながら，現 場での対応方法という実践まで落とし込んだテキス トとなっている.

ただ，残念ながら弊社でもすべての薬剤師がこの 
スキルを身に付け，活用しているとは言い難い状況 であるが，このスキルを生かした事例も報告されて いるのでいくつか紹介する.

（事例 1）一般用医薬品の鎮咳薬を求めて来局し た男性へのヒアリングにより，「咳き込むことが増 えた」という訴えを聞き，薬歴を確認したところ低 用量アスピリンを服用していることがわかり，薬剤 師より『食事中にむせることはないか ?』と質問し たところ Yes の回答であったため, 脳梗塞の再発 によって鱟下に影響が出ているのではないかと疑い 受診勧奨した.

（事例 2） 子供が車内で虫に刺されたと来局した 親に対し，詳しい症状をヒアリングするだけでなく 実際に確認したところ，1つ1つは虫刺症のようで あったが全身性であることに気付きウイルス性疾患 を疑い受診勧奨した。この患児は受診後，アシクロ ビルによる内服治療を開始した。

このように，薬剤師であってもそのスキルの差に よって患者を正しい治療へ導くことができるかどう かが左右される現状だが，現制度において，一般用 医薬品販売に係わる職種は薬剤師だけではない，指 定第 2 類 2435 品目，第 2 類 5726 品目，第 3 類 2917 品目. 計 11205 品目が市場に存在するのに対 し，要指導・第 1 類医薬品はたった 96 品目しか存 在しない.5)実に，99\%の一般用医薬品が，薬剂師 の手を，目を，思考に触れることなく販売され，服 用されていることは周知の通りである.

それは制度の責任なのか，薬剤師は，登録販売者 に仕事をとられたと嘆くだけでよいのか.いや決し てそうではない.

そこでわれわれは，一般用医薬品を購入するプロ セスにおける安全性を高めるために，この症候学的 スキルを適正使用の観点より，登録販売者に対して も，薬剤師から教育を行う取り組みを 2013 年度よ り始めた.

この講義では販売の可否，つまり薬剤師にリレー ションすべきタイミングを重点的に指導するのみな らず，一般用医薬品適応となつた場合に，養生法で あったり感染症であればマスクなど周辺商材の必要 性を説明したりすることでの感染拡大防止をも登録 販売者が意識できるようにしている.

高齢化が進めば医療費は増加する。そして同時に 一般用医薬品を購入する高齢者も増えるのである.
なぜなら，特に高齢化率の高い北九州市において は，クリニックよりも近い場所，便利のよい時間带 に，われわれのようなドラッグストアがあるためで ある．医療用医薬品を併用している人が増加してい るなか, より正しい判断を行うためには，登録販売 者で完結すべきでないケースを適切に薬剤師へ相談 することが求められる.

われわれは，次のような一例に出会った。それ は，一般用医薬品の小児用バファリン C II ${ }^{\circledR} の$ 成分 をアスピリンと勘違いして，一度に 3 箱購入しよう とした高齢男性に対して，登録販売者が状況の異常 に気付き，薬剤師に対応を依頼することで内容成分 が異なることのみならず，脳梗塞再発防止のために 治療継続を促すことができたケースである.このと き，登録販売者は事前に講義にてバファリンシリー ズの成分の違い，そして医療用アスピリンの用途に ついて説明を受けていたため，違和感を抱くことが できたとコメントしていた.

信じ難いケースであるが，実際にこのようなこと が起きてしまうのが一般用医薬品販売の実情なので ある.

これから薬剤師は, 要指導・第 1 類医薬品の販売 にしか責任を持たなくてよいのか？ 決してそうで はない．指定第 2 類，第 2 類・第 3 類の，山ほど存 在する一般用医薬品を効果的に操るために，自らは より職能を高めながら，他職種を教育するという責 務を負っているのだと，われわれは考える。

世界保健機関 (World Health Organization; WHO) が策定した 7 つ星薬剤師（Seven Stars Pharmacist） にも，われわれは学ぶだけでなく教育することが必 要だと明記されている。 ${ }^{6}$ そして, 決断し, 伝達 し，マネジメントするリーダーであることが望まれ ている.

ただし，ここで注意すべきは「マネジメント＝何 を言うか」と「リーダーシップ＝誰が言うか」は異 なる要素であり，双方ともに欠かせないということ だそそのような人材が薬学教育の中でスキルを身に 付け，社会に出てくることを望むとともに，われわ れのような現場の薬剤師は彼らが活躍する場を準備 しておかなければならない。

5. おわりに

これから必要となる薬学教育は,「顧客を複数の 側面から観察し，総合的な情報を仕入れ，把握する 
能力」そして「かならずしも完全でない主観的・客 観的デー夕を基に，顧客の状態を推測し今すべきこ とは何か? ?即断できる能力」だと考える.

そして，これらを実践できる薬剤師を輩出するた めの薬学教育を，この誌上シンポジウムに目を通さ れるであろうすべての薬学教員にお願いしたい，そ して，その教育対象は，薬学生に限らず既に社会に 出て実地で相談を受け，判断に悩むことが少なくな い筆者のような薬剤師に対しても拡げて頂きたい.

さらに, 症状の感度や特異度からどのような疾患 が，どの程度の頻度で存在するのかということを学 ぶ場を提供頂けることを願う。それが薬局・薬剤師 が国民に必要とされる存在となり，地域の医療介護 そして予防に効果を発揮する，大きな一歩となるは ずだ.

\section{利益相反 赤川信一郎（株式会社サンキュード} ラッグの社員)，森川則文（開示すべき利益相反は ない），池田佳代（開示すべき利益相反はない），岡 崎照夫（株式会社サンキュードラッグの社員），高 橋俊輔（株式会社サンキュードラッグの社員）.

森川則文が代表を務める「ファーマシストサポー ト」は株式会社サンキュードラッグとアドバイザー 契約を結んでいる.

\section{REFERENCES}

1) Ministry of Health, Labour and Welfare, "Required Functions and Ideal Situations of Phar- macy.": 〈http://www.mhlw.go.jp/seisakunitsuite / bunya / kenkou_iryou / iyakuhin / dl / 01-02.pdf $\rangle$, cited 7 March, 2014.

2) Ministry of Health, Labour and Welfare, "A Basic Direction for Comprehensive Implementation of National Health Promotion.": 〈http://www.mhlw.go.jp/stf/seisakunitsuite/ bunya / kenkou_iryou / kenkou / kenkounippon21.html $\rangle$, cited 23 September, 2013.

3) Prime Minister of Japan and His Cabinet, "Japan is back.": 〈http://www.kantei.go.jp/ jp / singi / keizaisaisei / pdf / saikou_jpn.pdf $\rangle$, cited 23 September, 2013.

4) Ministry of Economy, Trade and Industry, Ministry of Health, Labour and Welfare, "Utilization results of gray zone resolve system.": / http: / / www.meti.go.jp / policy / jigyou_saisei / kyousouryoku_kyouka/shinjigyo-kaitakuseidosuishin / result / release. html $\rangle$, cited 7 March, 2014.

5) Japan Pharmaceutical Information Center, "JAPIC Iryouyou Ippanyouiyakuhinshu Install version," January 2014.

6) World Health Organization (WHO), "The Role of the Pharmacist in the Health Care System-Preparing the Future Pharmacist: Curricular Development, Report of a Third WHO Consultative Group on the Role of the Pharmacist Vancouver, The seven-star pharmacist.": 〈http://apps.who.int/medicinedocs/ en/d/Js2214e/3.2.html $\rangle$, cited 7 March, 2014. 